\title{
Distance Education Program: Using Video Streaming to Improve Teachers' Competence
}

\author{
U. Dewi, Rusijono, F. Arianto \\ Universsitas Negeri Surabaya \\ Surabaya, Indonesia \\ utaridewi@unesa.ac.id
}

\begin{abstract}
This is a qualitative research which describes the implementation of distance education programs for teachers in East Java region by using video streaming, not having to meet teachers in the formal classroom environment such as traditional learning patterns. To collect data, the authors used observation and interview methods. To analyze, the authors used descriptive qualitative approach. The results of this study indicate that this program is implemented for justice in an effort to improve the competence and ability of teachers as professionals. The materials presented in the video streaming format include both theoretical and practical materials. The design of distance education was developed by utilizing streaming video technology. However, there has no been any evaluation research on distance education program so far. Thus, it is suggested to be evaluated to know the effectiveness of the program.
\end{abstract}

Keywords-Distance Educatio, Video Streaming, Teacher's Competence

\section{INTRODUCTION}

The United Nations in 2005 stated that one of the challenges of 21 st-century education is to build knowledgebased societies that have ICT and media literacy skills. This is a challenge for all educational components, especially teachers. Teachers as agents of reformers should synergize with the development of ICT and Media Technology that is growing rapidly. In addition, there is the need of learning which requires the use of ICT and media in it. Teachers must be computer literate to gain technological competence (Morrison \& Lowther, 2005).

As determined by the central government on the 2007 national education regulation no 16 for teachers and no 13 for principals on academic requirements or qualifications that principals and teachers should have the competence of utilizing ICT for self-development. In fact, the development of information technology has not been supported by the ability of teachers. Based on data from Persatuan Guru Republik Indonesia (PGRI) 2014, for example, of the 1.3 million competent competency test teachers, only 30 percent have been technologically literate. Infrastructure factors in each region do not always support teachers to technology literacy. The condition is different from teachers located in big cities, they are able to enjoy the development of information technology. While in a small town, the opposite condition due to lack of infrastructure. Yet mastery of ICT (technology, information, and communication) will help teachers more creative and innovative in solving problems, cooperation, seek information, and communicate [9]. To overcome these obstacles, East Java Provincial Education Office has held a training or workshop but this is not yet optimal because of the limited time of the training which is sometimes only two to four days which impact on the not optimal of mastering the material by the teacher as the trainee, so that impressed un-finished.

UPT-Tekkomdik (Education Communication and Information Technology) East Java Provincial Education Office considers it important to conduct Distance Education through streaming media that can be opened and developed in all districts/cities in East Java. One of the most important factors of the high level of distance learning program acceptance in the world, including Indonesia, is due to its high flexibility in eliminating the limitations faced by face-to-face education to provide access to education for all, such as age, geographic location, time constraints, and the economic situation (Gunawardena \& McIsaac, 2004; Baggaley, Belawati, and Malik, 2010). This program is implemented to improve the competence and ability of teachers at all levels of education. The material presented in video streaming format is audiovisual. The choice of material is also very diverse both theoretical and practical. The Design of Distance Education is developed by synergizing the learning model where the speaker is dealing with the presenter by utilizing streaming video technology [12]. Thus, it is expected that this program can improve the competence of teacher professionalism in East Java. Indonesia. The purpose of this study is to describe distance education programs for teachers in East Java region by using video streaming, not having to meet teachers in the formal classroom environment such as traditional learning patterns.

This is a qualitative research. To collect author data using observation and interview method. Data analysis technique used is descriptive qualitative. The results of this study indicate that this program is implemented for justice in an effort to improve the competence and ability of teachers as professionals. The material presented in the video streaming format includes both theoretical and practical material. The design of distance education was developed by utilizing streaming video technology. But so far there has been no evaluation research on distance education program, it is suggested to be evaluated to know the effectiveness of the program[12]. 


\section{METHOD}

This research is a type of qualitative research with data collection methods of observation and interviews. Data obtained through interviews with the head of UPTD Tekomdik East Java and Crew in Distance Education Program Using Video Streaming. Analysis techniques using qualitative descriptive analysis techniques. The results of the data obtained are analyzed and described in the form of descriptive exposure.

The technique of collecting data in this research was carried out by observation and interview with instrument observation and instrument interview. The observations were conducted by researchers to get an idea of the implementation of Distance Education using Video Streaming. Meanwhile, the interviews were carried out to get data about implementation goals and anyone involved in Distance education using Video Streaming. Data were obtained through interviews with the head of UPTD Tekomdik East Java and Crew in Distance Education Program Using Video Streaming.

Data analysis used in this research is qualitative descriptive analysis technique. With this technique, the data in the form of numbers and non-numbers were obtained from interviews and observations. Here, after describing or explaining, the researchers used a series of words in the form of sentences.

\section{RESULT AND DISCUSSION}

Distance education is a formal institution-based education where learners and their instructors are located in separate locations requiring an interactive telecommunication system to connect the two and the various resources required in it. Electronic learning (e-learning) or online learning is part of distance education that specifically combines electronic technology and Internet-based technologies [7]. In order for distance education to be more effective than traditional teaching, it should emphasize the presentation of interesting and communicative information, participation with feedback and access to existing learning resources (Smalldino, 2011). The widespread use of the internet by the public in various countries in 1996 became a growing phenomenon and followed by the emergence of a variety of digital content. In the same year, John Bourne developed the Asynchronous Learning Network Web that refers to the ability to provide education anytime and anywhere over the internet (Negash, 2008).

The distance education system, perceived as a 21 st-century innovation, is an educational system that has a wide reach, across space, time, and socio-economic. The distance education system opens access to education for anyone, anywhere, and any-time. Given these characteristics, the distance education system is often regarded as a solution to various educational issues, particularly with regard to equity and democratization of education, and the expansion of access to quality education to all levels of society[14]. Understanding Video Streaming is a communication made through broadcast internet access to produce an image. Technically streaming video is a sequence of "moving pictures" that are sent in a compressed form over the Internet and viewed by the user[8]. A complete streaming video system involves all the basic elements of creating, delivering, and ultimately playing video content. The main components of a complete streaming video system consist of
Encoding Station, Video Server, Network Infrastructure, and Client Playback.

Video streaming is nothing new for us in our homeland (Indonesia), since the advent of 3G (Generation Three) on a cellular video streaming telephone is everywhere, to the corners of the country. Actually the use of streaming video is long we have done, maybe we have forgotten our usage on Yahoo Messenger, Skype, youtube or the like, we've done before 3G mushroomed, around 2008, began to emerge television media in Indonesia using video streaming, such as Metro tv, a tv, Trans tv is now up to tv One.

Video streaming is actually a technology that makes it easier for us to get information in the form of video display, especially with the internet in all corners of the world, we more easily get information and entertainment without the need for regular television antennas or parabola. The convenience makes us feel more and more the world in the grasp, we can see the television, we can communicate with interactive $3 \mathrm{G}$ or through G-talk, Yahoo Messenger, Skype and other media is a benefit of a streaming video technology (Satwika,2011).

\section{A. Program Objective}

The presence of internet technology is accompanied by the presence of streaming technology [11]. Streaming technology is used to make faster downloads and play audio and video on the website, as it allows an audience to listen and view files while downloading. By synergizing these two things, UPTTekkomdik (Education Communication and Information Technology) East Java Provincial Education Office considers it important to conduct Distance Education through video streaming that can be opened and developed in all regencies/cities in East Java.

The purpose of this program is the distribution of efforts in improving the ability and competence of teachers spread in various areas in East Java. Despite there are training and workshop that is "pick up the ball" where the speakers come to teachers in the area, this is still not optimal. Limitations of distance and time sometimes become obstacles. Continuity and continuous training or workshops are required. Therefore, the Distance Education Appendix on Streaming which is displayed in Streaming Video format is expected to overcome these shortcomings [15].

Using the jargon of "a new era of educational information" Radio Pendidikan (Appendix) on Streaming developed by UPT Tekomdik East Java Provincial Education Office held a distance learning program. With streaming video format then audiovisual messages are very likely to be displayed and accessed anywhere and anytime. The learning materials presented are very diverse starting material that is both theoretical and practical. Such as material about Learning Media Rules and Development that shows how teachers can create interactive powerpoint media. Including the steps of development and technical manufacture [10].

\section{B. Target Programs}

The target of the distance education program varies according to education levels, distance education program for early childhood education teachers, distance education 
program for elementary school teachers, distance education program for junior high school teachers and distance education program for high school teachers. Therefore, the main target of this program is teachers from various levels of education from early childhood to high school. However, this program did not rule out so that it can be accessed by anyone who needs the meaning of this program. The material presented in video streaming format is audiovisual. The choice of material is also very diverse both theoretical and practical.

\section{Broadcast Time}

The material presented is also delivered in stages in accordance with the scheduled time. For example, the distance education program for junior high school with the "rules of development of learning media" broadcast on Tuesday and Thursday at $14.00 \mathrm{pm}$. Similarly, broadcast radio programs and broadcast television are generally scheduled at certain times. The average duration for once on air about 30 minutes.

\section{Place Of Progam Implementation}

Distance education program is conducted in a studio that complies with broadcast standards owned by UPT TEKOMDIK East Java Provincial Education Office located on the second floor, the Office of Provincial Education Office, Jagir, Surabaya, East Java, Indonesia

\section{E. Resource Person and Crew Program}

Resource persons as speakers in this distance education program are education practitioners, teachers, and lecturers from various universities in East Java. The resource person is an expert who has competence in accordance with the material presented. Some have expertise in the field of educational media, in the field of ICT, the field of psychology, science, social and other fields tailored to the material to be presented. Many parties are involved when on the air in the studio room, ranging from head of the production, cameraman, presenter, IT experts, technicians to resource persons as the central figure in this program. All together and have their respective roles for the success of this program.

\section{F. Program Implementation}

Distance learning courses are held directly with streaming video technology providing learning materials that can be accessed by teachers whenever and wherever they are. This program has been considered positively by audiences especially teachers from various education levels in East Java. To further solidify this program, UPT Tekomdik East Java Provincial Education Office regularly also held a training or workshop by inviting directly teachers throughout East Java in order to meet face to face with the speakers. This is to further strengthen the objectives of the program and to support the situation of direct interaction with resource persons who are impossible if this is done through Distance Education using Video Streaming.

\section{CONCLUSION}

The framework of equalization of educational and learning opportunities becomes one of the efforts to improve the competence of teachers in various regions in East Java UPT Tekomdik. East Java Provincial Education Office organizes Distance Learning program (PJJ) by using streaming video technology. It is also that can be accessed by teachers anywhere and anytime. The material presented in the video streaming format includes both theoretical and practical material. This program can overcome the constraints of space, distance and time. This PJJ pro-gram can be accessed at www.rapendik.com.

During the implementation of distance education program using video streaming should be evaluated about the achievement of this program so that it can be seen the benefits of increasing the competence of teachers in various levels of education[13]. Technical constraints need to be improved so that they can be accessed properly in order that, the program's objectives can be achieved.

\section{REFERENCES}

[1] Baggaley, J., Belawati, T., dan Malik, N. 2010. Distance education in the Asia Pacific: download 24 Agustus 2011 from http://web.idrc.ca/en/ev-140836-201-1-DO_TOPIC.html

[2] Gary. R. M. \& Deborah. L. 2005. Integrating computer technology into the classroom, 3rd edition. The UK. Pearson.

[3] Gunawardena, C.N., \& McIsaac, M.S. 2004. Distance education. In D. H. Jonassen (Ed.), Handbook of research on educational communications and technology 2nd ed., pp. 355-395. Mahwah, NJ: Lawrence Erlbaum.

[4] Negash, S. 2008. Handbook of distance learning for real-time and asynchronous information technology education. Information Science Reference; USA.

[5] Satwika, K. 2011. Streaming video process with the real-time streaming protocol. Thesis report department of electrical. Udayana University. Bali.

[6] Smalldino, E. S. 2011. Instructional technology and media for learning. Kencana Prenada Media. Jakarta.

[7] Simoson, Michael dkk. 2015. Teaching and Learning at a Distance Foundation of Distance Education. United States of American. Information Age Publishing. Inc.

[8] Shephard, K. 2003. Questioning, promoting and evaluating the use of streaming video to support student learning. British Journal of Educational Technology, 34(3), 295-308

[9] Dede, C. 2007. Reinventing the role of information and communications technologies in education. Yearbook of the National Society for the Study of Education, 106(2), 11-38

[10] Kafai, Y. B., \& Peppler, K. A. 2011. Youth, technology, and DIY: Developing participatory competencies in creative media production. Review of research in education, 35(1), 89-119.

[11] Chen, Rex, Oisze Lam, and Kenneth Kraemer. 2007. Strategic use of information technology-Google.

[12] Rosenstein, B. (2002). Video use in social science research and program evaluation. International Journal of Qualitative Methods, 1(3), 22-43.

[13] Halper, S., Kelly, K., \& Chuang, W. H. (2007). A Virtual Classroom Streaming System Designed for Large Classes. TechTrends, 51(2), 24 53.

[14] Faure, Edgar. 1972. Learning to be: The world of education today and tomorrow. Unesco.

[15] Taylor, James C. 1995. Distance education technologies: The fourth generation. Australasian Journal of Educational Technology 11.2. 